\title{
FESTA DOS MORTOS, RELAÇÕES DE SOCIABILIDADES E O CONSUMO DE MANICUERA
}

\author{
FEAST OF THE DEAD, SOCIABILITIY RELATIONS AND THE \\ CONSUMPTION OF MANICUERA
}

\author{
Maria Betânia Barbosa Albuquerque ${ }^{1}$ \\ Karen Azevedo Malar ${ }^{2}$
}

\section{RESUMO}

A partir de um diálogo teórico que encontra inspiração em Ariès, Da Matta e Brandão e com uma abordagem situada na confluência da antropologia com a educação, este artigo é decorrente de uma pesquisa de campo realizada no cemitério de Salinópolis (PA) e seus arredores, a partir da qual se busca analisar o preparo de uma beberagem (manicuera) exclusiva para o dia de finados. Com base em observações e entrevistas, o objetivo é analisar a rede de saberes que envolve a feitura da manicuera, bem como as relações de sociabilidade que caracterizam o dia da iluminação forjando, com isso, uma espécie de pedagogia do cotidiano.

\section{PALAVRAS-CHAVE}

Festa dos Mortos. Beberagens. Sociabilidade. Educação. Saberes.

\section{ABSTRACT}

The article aims to analyze the preparation of a drink (manicuera), made, exclusively, on the deceased's day, the perched knowledge and the relations of sociability that configure a daily life's pedagogy. It comes from a field survey at the cemetery of Salinópolis (PA) and its surroundings where, from observation and interviews, the day of the deceased, the material culture, the knowledge of manicuera, as well as its transmission to the other generations are described. It is located at the confluence of anthropology and education, relying on

1 Doutora em Educação pela Pontifícia Universidade Católica de São Paulo (PUC/SP), com Pós-Doutoramento pelo Centro de Estudos Sociais da Universidade de Coimbra (CES-Portugal) e Professora do Programa de Pós-Graduação em Educação da Universidade do Estado do Pará (UEPA).

2 Graduada em Ciências da Religião pela Universidade do Estado do Pará, UEPA, Brasil. 
Ariès, Da Matta and Brandão. The main means of the manicuera's knowledge transmission is observation since it is watching that one learns, and this depends more on apprentice's attentive posture than some didactic action of the teacher. It is common for women and men, still children, to watch their mothers and grandmothers prepare the manicuera to continue the tradition at the feast of the dead.

\section{KEYWORDS}

Feast of the Dead. Drinking. Sociability. Education. Knowledge.

Este artigo resulta de pesquisa de campo realizada no cemitério Nosso Senhor do Bonfim, localizado no município de Salinópolis - Pará e seus arredores. Durante o estido, foram realizadas observação e registros fotográficos com o objetivo de compreender como se organiza o dia da iluminação, bem como o preparo e a venda da manicuera. Os dados iniciais da pesquisa foram coletados em novembro de 2015 (com novo retorno a campo, no ano de 2016), por meio da observação na cidade, no cemitério e preparo da manicuera. Também realizamos entrevistas semiestruturadas com o padre da igreja matriz, com pessoas que preparam a bebida e com cerca de dez pessoas que circulavam dentro e fora do cemitério. Como parte da revisão bibliográfica, mantivemos contato com Salinópolis - $A$ cidade mais querida do Pará, de Benjamin Cardoso (2001); Salinópolis da Memória, de Dicão Ferreira (2010) e Sal Salinas Salinópolis, de Ailton Palheta (2003). Esses livros abordam questões históricas, estruturais, turísticas e religiosas que permitem um entendimento sobre a cidade e seu contexto sociocultural.

Teoricamente, o livro História da Morte no Ocidente do historiador Philippe Ariès (2003) foi fundamental para compreendermos as atitudes perante a morte e as transformações do seu significado na história. Em A morte é uma festa, João José Reis (1991) aborda a revolta da população de Salvador contra a construção de um cemitério, bem como os ritos fúnebres do século XIX, evidenciando o comportamento da sociedade em relação à morte e seus mortos. Para compreender as relações estabelecidas entre vivos e mortos tomamos como base o livro $A$ casa e a Rua de Roberto DaMatta (1997), que aborda a sociedade brasileira e toda a complexidade de suas relações e, em particular, como a sociedade compreende a morte. 
Um livro importante para a compreensão do uso de determinadas bebidas foi Beberagens Indígenas e Educação não escolar no Brasil Colonial, de Albuquerque (2012). Nele, a autora analisa o consumo indígena de uma bebida embriagante (cauim) e o modo como as práticas de beberagens articulavam um amplo conjunto de saberes baseados na oralidade e na experiência, funcionando como espaços de aprendizagens dos valores grupais e de construção de identidades.

A oralidade, nas culturas populares e comunidades tradicionais, tem sido objeto de estudo por diversas disciplinas como antropologia, literatura e história. As pesquisas no campo da educação, contudo, raramente veem a oralidade como processo educativo formador de subjetividades. Na obra A Educação como cultura, Brandão (2002, p.151) conjectura, a propósito, que "talvez o mundo das políticas, das práticas e dos estudos sobre educação tenha fechado e siga estreitando demais o círculo das suas questões", uma vez que tem privilegiado estudos restritos ao saber formal, escrito e escolarizado. Em vista disso, torna-se relevante expandir o alcance das reflexões sobre educação de modo a pensá-la para além dos muros da instituição escolar, incluindo, assim, processos sociais cotidianos baseados na experiência, e que informam modos de ser e estar no mundo de muitos grupos, como o que ocorre em Salinópolis, no Pará.

Esperamos com estas reflexões contribuir com o debate sobre festas típicas do catolicismo popular como instâncias de sociabilidades, com os estudos envolvendo o tema da morte e seus múltiplos sentidos e vivências. Fundamentalmente, esperamos contribuir com as pesquisas sobre as relações entre educação, oralidade e saberes culturais, particularmente, os mediados pela prática de beberagens, visando ampliar a noção corrente de educação marcadamente centrada na instituição escolar.

\section{Salinópolis em perspectiva geo-histórica e cultural}

Segundo Cardoso (2001), o município de Salinópolis surgiu a partir da povoação de índios tupinambás, seus primeiros habitantes. Mais tarde, outros índios também foram chegando ao município. Antes de se chamar Salinópolis seu primeiro nome foi "Virianduba" ou "Viriandeua", nome dado pelos próprios tupinambás, que significa "abundância de pássaros", 
em decorrência da grande presença de pássaros na região como: patos, guarás, maçaricos, tucanos, bem-te-vis, entre outros. Porém, com o aumento do povoamento e do processo de urbanização os pássaros foram se afastando.

O segundo nome do município foi "Destacado", atribuído por André Vidal Negreiros, governador geral do Maranhão (1655-1656), uma vez que, nessa época, o atual território do Pará pertencia ao Maranhão. O então governador percebeu que deveria dar orientação aos navegantes e, por isso, destacou alguns práticos e no morro da ilha do Atalaia ordenou que colocassem um canhão para que os disparos alertassem os mesmos. Confirma Cardoso (2001, p. 12) que "sendo os pilotos destacados no próprio local, passou, então, o município a ser chamado de Destacado". Desse modo, Virianduba virou Destacado e, posteriormente, Destacado foi substituído por Salinas considerando a presença de uma pequena salina ao longo do período colonial. De acordo com o acervo histórico pertencente à Biblioteca do Instituto Brasileiro de Geografia e Estatística (IBGE), em 1943 Salinas passou a se chamar Salinópolis, como atualmente é conhecida.

A partir de dados do IBGE, o município de Salinópolis conta com uma população aproximada de 39.328 habitantes, espalhada em uma área territorial de $242 \mathrm{~km}^{2}$. Está situado na parte oriental do Estado do Pará, na mesorregião do nordeste paraense, na microrregião do Salgado entre o Atlântico, situado ao norte, e a Baia do Marajó, situada a oeste e ao sul. Ao longo dos anos, Salinópolis foi se modificando política, social e culturalmente, particularmente, no que diz respeito aos aspectos estruturais, econômicos e turísticos. Nos anos 40 do século XX, esse município experimentou um "desordenado" crescimento populacional e urbanístico, cujas foram

são os grandes contrastes, de um lado o loteamento Atalaia com um sistema de especulação imobiliária sem infraestrutura adequada e pagamentos de impostos mal resolvidos; do outro lado temos ruas e avenidas mal traçadas que resultam de uma série de ocupações e que com o decorrer da extensão territorial do município a cidade não adquiriu nenhum tipo de elaboração ou plano de estruturação e ocupação das terras, logo a cidade cresceu apresentando um grande contraste entre nativos empobrecidos com pouco direito de legalização nas terras e, veranistas afortunados que obtiveram suas 


\section{ARTIGO}

moradias temporárias (habitadas somente nas férias) (CARDOSO, 2001, p. $30)$.

O processo de crescimento urbanístico está relacionado ao incentivo da atividade turística, um meio de valorização muito característico de cidades litorâneas, porém sem os devidos cuidados socioambientais. Do ponto de vista educacional, no município existem onze escolas da rede estadual, sendo que nove localizam-se na zona urbana e duas na zona rural. Existem três escolas de ensino médio, todas da rede estadual. A rede municipal tem vinte e quatro escolas, sendo que dezesseis localizam-se na zona urbana e oito localizam-se na zona rural. Segundo Palheta (2003), o município também tem uma biblioteca pública e uma escola de música. Conta também com uma Associação de Artistas Plásticos e Artesãos e um complexo esportivo e cultural onde são praticadas diversas modalidades de esporte e shows musicais.

As manifestações culturais de Salinópolis envolvem festas populares juninas, os chamados cordões juninos, as quadrilhas, grupos folclóricos de pássaros e bichos, e o boi-bumbá os quais já foram bastante prestigiados no passado. Porém, com o passar do tempo, o interesse e o incentivo do poder público às manifestações culturais foram diminuindo. Uma manifestação da cultura popular muito forte em Salinópolis é o carimbó. Palheta pontua que:

Danças de origem afro-ameríndia, inseridas, portanto, na raiz étnica de nossa ancestralidade, as rodas de carimbó continuam a sacudir a sensibilidade paraoara. Em Salinópolis tal manifestação cultural é muito mais acesa e sentida e dançada por pares de homens e mulheres com arrasta-pé singulares, negaças de corpo e bamboleios provocantes de inimitável coreografia (PALHETA, 2003, p. 20).

Além do carimbó, outro aspecto característico de Salinópolis é a diversidade de praias que chamam atenção dos turistas, sendo a praia do Maçarico, localizada na antiga frente da cidade, a mais famosa. A cidade também se destaca pela religiosidade diversificada uma vez que possui igrejas católicas, protestantes, pentecostais e terreiros afro-indígenas. O catolicismo popular também se faz presente no município através da crença em seres sobrenaturais corporificados em visagens, assombrações, 
vultos e encantados. Somam-se a isso as lendas amazônicas compondo o imaginário popular do povo local. Todavia, a despeito da diversidade religiosa, o catolicismo é preponderante motivo pelo qual durante o ano ocorrem diversas festividades para vários santos. A festa tradicional é a de Nossa Senhora do Socorro, padroeira do município, que ocorre no dia 8 de setembro. Porém, embora a festividade de Nossa Senhora do Socorro seja a mais lembrada, a festa de São Pedro, que ocorre em junho, conta com maior participação popular, sobretudo, de pescadores, pois esse seu santo protetor.

A despeito da existência de uma diversidade de arraiais ou festas de santos, em Salinópolis destaca-se um tipo singular de arraial ocorrido no cemitério durante o dia de finados que, especificamente, não está ligado a nenhum santo.Trata-se do culto aos mortos ou ritual de iluminação.

\section{O dia da iluminação ou o arraial dos mortos em Salinópolis}

Desde o século XVIII o homem da sociedade ocidental compreende a morte a partir de variados sentidos, segundo Ariès, exaltando-a, dramatizando-a ou desejando-a de forma

impressionante e arrebatadora. Mas, ao mesmo tempo, já se ocupa menos de sua própria morte, e, assim, a morte romântica, retórica, é antes de tudo a morte do outro - o outro, cuja saudade e lembrança inspiram, nos séculos XIX e XX, o novo culto dos túmulos e dos cemitérios (ARIÈS, 2003, p. 64).

Tem-se, assim, a presença do luto que, no término da Idade Média até o século XVIII, tinha duas intenções:

Por um lado, induzia a família do defunto a manifestar, pelo menos durante um certo tempo, uma dor que nem sempre experimentava [...]. Por outro lado, o luto tinha também o efeito de defender o sobrevivente, sinceramente submetido à provação, contra os excessos da dor, pois impunha-lhe um certo tipo de vida social, as visitas de parentes, vizinhos e amigos que lhe eram feitas e no decorrer das quais a dor podia ser liberada sem que sua expressão ultrapassasse, entretanto, um limite fixado pelas conveniências. Ora - e este é um ponto muito importante -, no século XIX esse limite não mais foi respeitado, o luto se desenrola com ostentação além do usual. Simulou até não estar obedecendo a uma obrigação mundana e ser a expressão mais espontânea e mais insuperável de uma gravíssima dor: chora-se, desmaia-se, desfalece-se e jejua-se (ARIÈS, 2003, p.71). 
Ainda segundo Ariès, é justamente esse luto excessivo que vai originar o culto moderno dos túmulos e dos cemitérios posto que na Idade Média os mortos não tinham assim tanta atenção. Ao contrário, "pouco importava o lugar exato de sua sepultura que, na maior parte das vezes, não era indicada nem por um monumento nem mesmo por uma simples inscrição” (ARIÈS, 2003, p. 73). Desde o século XIV e, sobretudo, no século XVII, já se observa a preocupação mais frequente em se localizar a sepultura do morto. A partir do culto moderno, as pessoas começam as visitações aos túmulos de entes queridos como se estivessem indo à casa de um parente. É como se o túmulo fosse a nova morada do morto, e sua memória lhe concedesse imortalidade. Desse modo,

o culto da lembrança imediatamente estendeu-se do indivíduo à sociedade, seguindo um mesmo movimento da sensibilidade. Os autores de projetos de cemitérios do século XVIII desejam que estes sejam ao mesmo tempo parques organizados para a visita familiar e museus de homens ilustres [...] os túmulos dos heróis e grandes homens seriam venerados pelo Estado em tal local [...]. Pensa-se, e mesmo sente-se que a sociedade é composta ao mesmo tempo de mortos e vivos, e que os mortos são tão significativos e necessários quanto os vivos (ARIÈS, 2003, p. 76).

No âmbito deste estudo, as contribuições de Ariès inspiraram a reflexão sobre o culto aos mortos que é realizado no dia 2 de novembro, no cemitério municipal Nosso Senhor do Bonfim, em Salinópolis, Pará. Trata-se de uma tradição muito antiga, conhecida como dia da iluminação, arraial da iluminação ou ritual de iluminação, momento em que as pessoas prestam homenagens aos seus entes queridos lá enterrados. O nome "iluminação" é uma referência ao fato de que o cemitério durante a noite fica completamente iluminado dada a quantidade de velas acesas destinadas às almas dos mortos. Entretanto, embora a iluminação seja mais visível a noite, o dia da iluminação começa assim que o cemitério abre, por volta das oito horas, quando vão chegando as pessoas para prestarem suas homenagens.

As observações de campo permitiram-nos constatar que o dia da iluminação pode ser dividido em etapas: primeiro tem a limpeza dos túmulos, normalmente pela parte da manhã para, a noite, realizar-se a etapa da iluminação dos mortos que já estão com seus túmulos limpos e 
decorados com flores e guirlandas. Ao fim da iluminação tem-se um tipo de confraternização ocorrida no arraial formado ao redor do cemitério. As homenagens são feitas de diversas formas: pelo simples ato dos parentes levarem flores aos túmulos; pela limpeza destes a fim de retirar o mato que ali nasceu; pela lavagem das sepulturas, para a retirada do limo e até mesmo sua reforma e pintura.

Os que limpam os túmulos dificilmente vão sozinhos ao cemitério, pois é possível observar homens e mulheres realizando essa atividade e, na maioria das vezes, com a companhia de crianças. As pessoas chegam portando objetos como baldes, garrafas de água, vassouras, escovas, latas de tinta e pincéis para auxiliar nos diversos trabalhos de limpeza e arrumação dos túmulos. Portanto, pela parte da manhã, é mais comum a arrumação e limpeza para que, durante a noite, seja realizada a iluminação das sepulturas com os demais integrantes da família do morto.

DaMatta salienta que, no Brasil, o dia de finados ou dia dos mortos assume enorme popularidade, pois é uma "ocasião em que as famílias visitam o cemitério e lembram os 'seus mortos' mais queridos ou mais recentes" configurando um tipo específico de relação social. Para esse autor:

Vivemos em um universo onde os vivos têm relações permanentes com os mortos e as almas voltam sistematicamente para pedir e ajudar, para dar lições de humildade cristã aos vivos, mostrando sua assustadora realidade. Na nossa sociedade, os espíritos retomam para assegurar a continuidade da vida mesmo depois da morte, e os fantasmas aparecem para revelar que nossa vida material é relativa e que há outra realidade permanente por trás de tudo o que julgamos saber (DAMATTA, 1997, p. 107).

Para o autor, o culto aos mortos implica em relações sociais entre vivos e mortos que constituem "um verdadeiro padrão de moralidade nas religiões populares":

O que se cultua realmente são as relações e as possibilidades (e esperança) de relações entre os dois lados da vida. De um lado temos os médiuns vivos, do outro os espíritos e deuses que ‘baixam' para nos dar mensagens e estabelecer contato conosco, garantindo a eternidade da vida. Esses duplos mediadores nos asseguram a permanente continuidade entre a vida e a morte, sob o enquadramento de ideologias em que a compensação pelo outro mundo é 


\section{ARTIGO}

visível e altamente funcional, e a ideia de renúncia ao mundo é uma marca registrada (DAMATTA, 1997, p. 115).

Em Salinópolis, a observação do cemitério revelou que, apesar de o dia de finados ser um dia comumente associado à tristeza, ele não é visto apenas por esse ângulo do luto, mas também como um modo das pessoas se relacionarem entre si ao reunirem-se para prestar homenagens aos mortos, formando um pequeno arraial ao redor do cemitério. Desse modo, o dia da iluminação se configura como momento de encontro de pessoas, familiares e amigos e, mesmo que para velarem os mortos, termina sendo um momento de confraternização, alegria e coesão social. Um tipo de relação entre vivos e mortos que sintetiza uma espécie de ponto "culminante na maior homenagem aos mortos que é realizada em Salinópolis no Dia de Finados. Trata-se de um ritual que pode ser caracterizado como um momento de confraternização onde laços sociais são fortalecidos e renovados" (NEGRÃO, 2014, p. 42).

Ainda acompanhando as reflexões de Negrão, ganha evidência a perspectiva de naturalidade com que o fenômeno social da morte é visto em Salinópolis. Para ele,

o contexto de Salinópolis apresenta, através do ritual de homenagem aos mortos, indicações de que o convívio com a possibilidade de morrer é algo mais naturalizado naquele contexto sociocultural. Ou seja, há certa predisposição em tornar "familiar" um fenômeno social (a morte) do qual, geralmente, se pretende estar afastado. É por este motivo que o ritual de iluminação dos mortos em Salinópolis é vivido, na maioria das situações que observei, como um acontecimento familiar, envolvendo crianças, idosos, homens, mulheres e adolescentes (NEGRÃO, 2014, p. 56).

O cemitério Nosso Senhor do Bonfim não é muito grande e possui apenas uma alameda principal, com piso de cimento, que dá acesso à capela e ao escritório da administração. Uma vez que esse é o único cemitério do município, no dia da iluminação, o mesmo fica superlotado, dificultando a locomoção dos visitantes, inclusive, pela posição das sepulturas, geralmente, muito próximas umas das outras, fato que, quase sempre, obriga as pessoas a pisarem sobre elas em busca de melhor circulação.

Nesse dia, pela manhã já se observa certa movimentação com a armação de algumas (poucas) barracas de comidas nos arredores do 
cemitério. Também é possível observar um grande número de mototáxi pelo fato da frota de ônibus em Salinópolis ser escassa, além de que nenhuma das linhas passa perto do cemitério. Por essa razão, aumenta a procura por moto-táxi e táxi.

Embora a movimentação de pessoas seja intensa durante todo o dia, pela parte da noite esse fluxo duplica, sendo que o quarteirão do cemitério fica completamente fechado em função do grande número de pessoas que por ali circulam. Com isso, também é grande o número de barracas onde são vendidas, geralmente, comidas tradicionais da culinária paraense. Além das barracas de comida, destacam-se os carros de lanches, pipoca e churros e o famoso "churrasquinho de gato". Há também venda de balões e outros brinquedos industrializados. Assim, o dia da iluminação, além de ser um dia religioso é também um dia comercial na medida em que movimenta uma pequena economia local, seja por causa dos moto-táxis ou táxis, seja devido aos ambulantes que ali se concentram para vender seus diversificados produtos.

Cabe ressaltar que, entre o fluxo de pessoas durante a noite, tanto dentro quanto fora do cemitério, encontra-se um grande número de jovens. Por isso, nesse espaço ocorre não apenas uma movimentação de renda aos moradores ou o culto aos mortos, mas também um ponto de encontro entre amigos ou namorados. O cemitério configura-se, portanto, como espaço de sociabilidades, trocas e circulação de saberes. As refletir sobre isso, Negrão que:

O cemitério passa a ser ponto de encontros amorosos entre adolescentes, que, desacompanhados de algum adulto, chegam no início da tarde para acender velas e aproveitam a ocasião para flertarem entre si. Muitos apenas acendem as velas e não esperam serem consumidas pelo fogo. No entanto, à tarde, o número de adolescentes ainda é reduzido, comparado aos que frequentam a iluminação no período noturno (NEGRÃO 2014, p. 113).

Para entender o que leva as pessoas a irem ao cemitério no dia da iluminação foram realizadas algumas entrevistas. Entre elas, destaca-se a fala de uma moradora local, Lucidalva, de 56 anos que, ao ser indagada sobre o que foi fazer no cemitério, respondeu: "Só olhar e acender vela em cima de meus parentes que estão aqui". Ao ser indagada sobre o significado 
do dia de finados, respondeu: "É dia de acender vela, feriado e dia de todos os santos". Na mesma direção, responderam outros entrevistados que residem na região de Salinópolis: para D. Lúcia, de 58 anos, o dia de finados representa o dia de "acender velas para os entes queridos, para a família que já é falecida. Lembrar deles porque rever a gente não vai rever é impossível, então a gente vem acender vela e se sente feliz e bate aquela saudade"; Seu Luiz Gonzaga, por sua vez, afirmou que foi ao "cemitério alumiar a minha mãe. Para ele, o dia de finados é um dia meio triste porque a gente vem 'alumiar' um ente querido nosso".

Mas, outros motivos também levam as pessoas ao cemitério: D. Maria Helenice, de 43 anos, respondeu que foi ao cemitério "tomar essa iguaria" [a Manicuera]. Ao refletir sobre o significado do dia da iluminação, respondeu que:

Iluminação quer dizer luz, eu creio, o pessoal tem mania de "ilumiar" só em uma data, mas eu creio que isso aí, independente disso a gente tem que fazer as visitações para os seus mortos, não precisa "ilumiar", não precisa acender uma vela, eu penso assim. Eu tenho parente aí, mas como eu sou evangélica não faço parte disso, mas a qualquer dia eu posso vir aí fazer uma visita, orar.

Além do culto aos mortos e independente de crenças religiosas, diversos motivos levam as pessoas ao cemitério. Há quem vá ao local apenas para olhar o movimento, para procurar algo para comer nas barracas, para namorar ou para se divertir com os amigos. Porém, o motivo maior ainda é o de prestar homenagem a algum parente ou amigo que já se foi desta vida e que está lá enterrado:

A Iluminação dos Mortos em Salinópolis é mantida como ritual na medida em que os vivos desejam reforçar seus vínculos com os mortos. Assim, o ritual evidencia e equilibra, ainda que momentaneamente, as necessidades de reintegração manifestadas por ambas as partes, vivos e mortos, reintegrando os vivos à dimensão espiritual e os mortos à vida social (NEGRÃO, 2014, p. $34)$.

Para Sanchis, um conjunto de atividades são desencadeadas de modo a identificar o arraial como espaço de sociabilidade, como uma festa:

aí se canta, aí se dança, aí se toca música, aí se come, aí se fazem trocas e comércio [...] o arraial-espaço é assim lugar de uma socialização intensa, mas fugaz, dominada pela liberdade relativamente às regras, a ausência de trabalho, 


\section{ARTIGO}

a gratuidade. É a comunidade reencontrada e alargada, é a nova Jerusalém onde somente ressoam os cantos e a música, aí se reúnem todas as atividades humanas (SANCHIS, 1983, p. 143).

As festas, conforme Silva e Miguez (2014), assumem um lugar especial com significados culturais próprios. Dependendo do contexto, a festa pode diluir, cristalizar, celebrar, ironizar, ritualizar ou sacralizar a experiência social própria dos grupos que dela participam. Dessa maneira, "apesar de as manifestações religiosas ganharem traços cada vez mais individuais, a religiosidade e as festas permanecem atuando na reativação da memória coletiva" (LEONEL, 2010, p. 7) e, consequentemente, "a memória de tais práticas religiosas possibilita, nos presentes arranjos sociais, a legitimação de práticas e a sobrevivência de identidades e valores" (LEONEL, 2010, p. 10). O arraial da iluminação, portanto, está inserido no contexto da cultura popular e das festas. Estas,

compreendidas como formas de sociabilidade, passaram a significar as próprias formas de ser, estar e de se relacionar em sociedade. As festas, religiosas ou não, foram colocadas como fenômenos a serem estudados na sociedade e em relação a ela, tanto no passado como no presente. $\mathrm{E}$ isso significou, ao mesmo tempo, considerá-las fenômenos sociais, que estão na razão mesma de existência da sociedade e dos vínculos sociais, assim como, portadores de uma dinamicidade capaz de dotá-la do potencial de se revestir de múltiplos significados e práticas (LEONEL, 2010, p. 12).

Ao analisar os ritos fúnebres da Bahia do século XIX, Reis destaca que os baianos tinham grande fascínio por eles:

Festas em torno de imagens de cadáveres, essas procissões parecem ter servido de modelo para os antigos funerais brasileiros, verdadeiros espetáculos. As procissões do Enterro, em especial, teatralizavam o funeral apoteótico de um Deus vitorioso, a quem os fiéis desejavam reunir-se quando mortos. Imitandoas, os cortejos fúnebres encenavam a viagem rumo a esse reencontro. A pompa dos funerais - e por que não chamá-los de festas fúnebres? - antecipava o feliz destino imaginado para o morto e, por associação, promovia esse destino (REIS, 1991, p. 138).

Além disso, os ritos fúnebres tinham suas próprias normas e tabus, funcionando ainda como elemento de transgressão às normas locais:

Em nome da boa morte, os fiéis rompiam com as normas da Igreja, que proibia os funerais noturnos, os insistentes dobres de sino e música na rua 


\section{ARTIGO}

[...]. Os cortejos fúnebres aconteciam ao anoitecer, sendo acompanhados de um grande número de conhecidos, encabeçados por padres, cada um levando uma vela coberta com uma lanterna de papel ou tocheiros [...]. Os horários dos enterros, à noite, talvez representasse um fator de integração do morto em seu novo mundo, enquanto a queima de vela simbolizava a vida que se extinguia e a iluminação do caminho para a vida eterna. Um rico jogo mágico orientava os cortejos (REIS, 1991, p. 139).

Ainda, conforme Reis, toda festa realizada em volta dos mortos importava acima de tudo para os vivos, como forma de reconstituição da própria vida. Por isso, ele afirma que por meio dela as pessoas

expressavam suas inquietações e procuravam dissipar suas angústias. Pois embora variando a intensidade, toda morte tem algo de caótico para quem fica. Morte é desordem e, por mais esperada e até desejada que seja, representa ruptura com o cotidiano. Embora seja seu aparente contrário, a festa tem atributos semelhantes. Mas, se a ordem perdida com a festa retorna com o final da festa, a ordem perdida com a morte se reconstitui por meio do espetáculo fúnebre, que preenche a falta do morto ajudando os vivos a reconstruir a vida sem ele [...]. O espetáculo fúnebre realmente distraía o participante da dor, ao mesmo tempo que chamava o espectador a participar da dor. Reunidos solidários para despachar o morto, os vivos recuperavam algo do equilíbrio perdido com a visita da morte, afirmando a continuidade da vida (REIS, 1991, p. 138).

Para esse autor, a morte, como motivo de festa, tem apreciadores em todas as classes sociais. Dessa forma, o barulho no lugar do silêncio se junta aos ritos fúnebres em diferentes sociedades, pois é interpretado como auxiliar na comunicação entre o homem e o sobrenatural. Negrão, por sua vez, afirma que a confraternização se expressa na aglomeração festiva de pessoas que terminaram de iluminar seus parentes falecidos e depois se concentram no arraial para momentos de sociabilidade e comensalidade. Tais momentos são perpassados pelas conversas entre amigos e familiares e pelo consumo de comidas típicas que são vendidas nas barracas do arraial. Assim, até mesmo o espaço do cemitério é capaz de proporcionar sociabilidades entre os vivos, mesmo parecendo um lugar incomum para que isso ocorra:

Ao ter seus mortos e túmulos iluminados, o cemitério também lança luz sobre as relações que os vivos estabelecem entre si. Aqueles que há muito não se viam são os mais calorosos ao encontrar algum conhecido. Embora a finalidade 
maior do ritual seja iluminar os mortos, não é raro encontrar pessoas que não residem na cidade há algum tempo e que retornam para lá nesta data porque sabem que há grande possibilidade de encontrar muitos conhecidos durante a confraternização [...]. No Dia de Finados, o Cemitério do Bonfim é o local ideal para ver e ser visto. É uma data ideal para reencontrar as pessoas, saber notícias de conhecidos, contar novidades aos amigos e rever parentes, anunciar casamentos, separações conjugais, gestações, nascimentos ou, obviamente, mortes. No trânsito pelo cemitério, abraços apertados e expressões de afeto se contrapõem ao silêncio de quem ainda está iluminando a sepultura familiar (Negrão, 2014, p. 127).

É durante o momento de confraternização no arraial dos mortos que aumenta o número de jovens circulando. Muitos deles, desacompanhados dos pais ou responsáveis, se divertem com amigos ou namorados e aproveitam para consumir os lanches vendidos nas barracas. Costumam chamar de arraial por causa da descontração presente que:

impera na confraternização vivida na rua, contrastando com o aspecto mais sacralizado da iluminação empreendida no interior do cemitério. Embora haja momentos de descontração, risadas e diálogos durante a iluminação dos mortos, estes são sempre alternados por grandes instantes de silêncio ou de proferimento de preces. Famílias inteiras vão embora a partir das 20 horas e o número dos que partem, neste momento, é superior aos dos que chegam. No entanto, a quantidade de jovens no arraial é maior. Há vários grupos de jovens circulando pela rua ou parados em pontos próximos uns dos outros. Casais namoram encostados no muro do cemitério, enquanto outros jovens conversam, através do muro, com os que estão iluminando dentro do cemitério, tendo suas risadas e gargalhadas ouvidas, até mesmo, a uma certa distância (NEGRÃO, 2014, p. 133).

Contudo, a característica mais marcante do dia da iluminação que ressaltamos neste texto, é sem dúvida, a venda da manicuera, beberagem de origem indígena encontrada e consumida, exclusivamente, nesse dia.

\section{O preparo e a transmissão dos saberes da manicuera}

Em Salinópolis, uma das grandes atrações do dia da iluminação é, sem dúvida, o consumo da manicuera, que vendida durante o dia inteiro. Vale ressaltar, que o ano todo a manicuera somente é encontrada à venda durante no dia de finados. Era comum encontrar a manicuera nas festas de santo, mas com o aumento da comercialização de bebidas industrializadas o costume foi se perdendo chegando às vias de extinção, restringindo-se 
apenas ao dia de finados. Segundo a tradição local, ingerir a manicuera nessa data é uma forma de homenagear os mortos. É possível conjecturar que o uso contemporâneo da manicuera no dia de finados seja uma possível ressignificação das antigas práticas dos tupinambá. Embora a manicuera não seja uma bebida embriagante, seu significado assemelha-se ao das bebidas ingeridas pelos tupinambá visando homenagear o morto, pois para eles "a morte dos entes queridos constituía ocasião para beberagens, sendo as bebidas servidas pelos parentes do falecido como forma de homenagem a este” (ALBUQUERQUE, 2012, p. 97).

Para melhor compreender o processo de fabricação da manicuera foram realizadas entrevistas com dona Neuri, uma senhora de 66 anos, moradora do bairro São Vicente em Salinópolis. Dona Neuri tinha uma barraca de tacacá e durante a festividade de São Pedro, além do tacacá, vendia também outras comidas típicas. O mesmo acontecia no dia da iluminação onde, além das comidas, vendia manicuera. Ela afirmou que aprendeu a fazer manicuera ainda muito pequena ao ajudar sua mãe nesse preparo, quando tinha mais ou menos seis anos de idade.

O preparo da manicuera é repassado de geração a geração e não é restrito apenas às mulheres. Em 2015, observamos o preparo da manicuera sendo realizado no quintal da casa de dona Neuri. Em 2016, observamos esse fato também na casa da dona Neuri, porém quem estava à frente da função era seu genro, posto que a mesma estava hospitalizada em Belém, vindo posteriormente a falecer. A manicuera é uma bebida feita de uma raiz chamada mandiocaba que é plantada na roça e colocada à venda na feira do município. O processo de preparo da bebida acontece da seguinte maneira: primeiro lava-se a mandiocaba para retirar toda a terra. Em seguida ela é ralada e espremida no tipiti [um instrumento de origem indígena utilizado na prensagem da mandioca feito, geralmente, de palha trançada] para, enfim, ir ao fogo onde deve ser cozida por cerca de seis horas. Após o cozimento a manicuera ganha consistência e, então, acrescenta-se uma espécie de arroz vermelho para cozinhar por mais uma hora e meia.

A cultura material que envolve o preparo inclui: o uso do tipiti para espremer a mandiocaba, colheres grandes de pau para mexê-la enquanto ferve e panelas grandes, geralmente de alumínio. Ao observar a fabricação 
da manicuera, percebemos que seu Paulo recebia a ajuda de alguns familiares: duas moças lavavam as mandiocabas, enquanto um rapaz lavava as que já estavam limpas. Enquanto isso, seu Paulo mexia a manicuera que já estava na panela cozinhando.

No ano de 2016 todas as etapas do preparo ocorreram à noite em frente à casa da dona Neuri, chegando até a madrugada, por causa das mais de cinco horas de cozimento necessárias. Porém, em 2015, as etapas de lavar, ralar e espremer a mandiocaba foram realizadas no quintal e apenas o processo de cozimento foi feito em frente à casa, durante o dia até chegar a noite. Do outro lado da rua, em frente à casa de dona Neuri, foi feita uma fogueira onde colocou-se a panela com a mandiocaba para ferver.

Durante o processo, a família de dona Neuri ajudava de alguma forma e todos conversavam em um verdadeiro momento de descontração e sociabilidade no qual os saberes da manicuera eram socialmente repassados, configurando uma pedagogia do cotidiano pautada na oralidade. Dentre os saberes, aprende-se que não se adoça a manicuera. O gosto doce é próprio dela, assim como uma leve consistência alcoólica também lhe é própria. É comum a manicuera ser servida fria, pois quente poderá causar dor de barriga. Todavia, há quem a prefira gelada. O consumo de manicuera não tem restrição. Entretanto, pessoas com diabetes têm receios de tomá-la por causa do gosto adocicado.

O saber da manicuera pode ser entendido como um saber cultural fincado na experiência e no cotidiano social de determinados grupos. Embora seja um saber ancorado na história de diversas cidades do Pará, ele não está vinculado à educação escolar que, em geral, o ignora. Porém, tal como o saber científico, ele é composto de sistematização, regras, organização e complexidade, exigindo um tipo particular de inteligência. Reportando-se às sutilezas que caracterizam os saberes culinários Lucy Giard afirma que:

Desde que alguém se interessa pela arte culinária, pode constatar que ela exige uma memória múltipla: memória de aprendizagem, memória dos gestos vistos, das consistências [...]. Exige também uma inteligência programadora: é preciso calcular com perícia o tempo de preparação e cozimento, intercalar as sequências umas às outras, compor com a sucessão dos pratos para atingir 


\section{ARTIGO}

o grau de calor desejado no momento adequado: por exemplo, é inútil que os filhós de maçã da sobremesa estejam no ponto quando os convivas mal estão nos aperitivos (GIARD, 2009, p. 219).

$\mathrm{Na}$ operacionalização desse tipo de saber outros fatores concorrem como a visão, o tato, o paladar, ou seja, toda uma sensibilidade corporal que remete à própria etimologia da palavra saber enquanto sabor. Para Giard, a "receptividade sensorial também intervém", posto que "mais que o tempo teórico de cozimento indicado na receita, o que informa sobre a evolução do cozimento e sobre a necessidade de aumentar ou diminuir o calor é o cheiro que vem do forno (GIARD, 2009, p. 219). De modo similar, os saberes culinários que perpassam o preparo da manicuera incluem sentidos como tato, paladar, visão e olfato. Sentidos necessários para saber se o fogo à lenha está adequado, se as seis horas de cozimento da mandiocaba foram cumpridas, mais uma hora e meia de cozimento junto com o arroz vermelho, além da capacidade de saber o ponto exato da transformação da mandiocaba cozida em manicuera.

O saber da manicuera é, assim, um saber da experiência repassado de geração a geração por intermédio da oralidade, ou seja, a partir de uma transmissão cultural de saberes que caracteriza momentos de socialização e educação. O principal meio de transmissão dos saberes é através da observação, posto que é observando que se aprende e esse ato depende mais de uma postura atenta do aprendiz do que de uma ação didática de quem ensina. Desse modo, é comum mulheres e homens, ainda crianças, observarem suas mães e avós prepararem a manicuera para, assim, aprenderem e darem continuidade a essa prática e, com isso, contribuírem para que a tradição de fazer e beber a manicuera no dia de finados não se perca.

Compreendida como educação do cotidiano, a transmissão desses saberes não implica um gesto intencional de ensino, pois a fabricação da manicuera não pressupõe a presença de um professor ou uma pessoa mais letrada à frente do processo. A despeito disso, a transmissão de saberes ocorre do mesmo jeito e o costume de beber manicuera atravessa as fronteiras do tempo perpetuando-se entre gerações. Esse fato configura a 
experiência do seu feitio como uma experiência pedagógica que contribui para o fortalecimento dos laços culturais e identitários.

Concluindo, o se procurou aqui foi demonstrar como o dia da iluminação (ou o dia de finados) é vivenciado no município de Salinópolis (PA), cuja visita ao cemitério é marcada por homenagens, sentimento de tristeza, mas também de alegria e busca de confraternização entre vivos e mortos, assim como entre os próprios vivos. Procuramos ainda evidenciar que o consumo de manicuera, ocorrido exclusivamente no dia da iluminação, é uma das grandes atrações desse dia, constituindo-se como fonte de renda extra aos moradores que decidem montar barracas ao em torno do cemitério, além de importante mediador cultural e de relações sociais.

A festa, por sua vez, configura-se como espaço de transmissão e circulação de saberes e sua realização garante a preservação da tradição do arraial da iluminação, perpetuando o ritual de consumo da manicuera e seus múltiplos saberes. No processo de fabricação, estão presentes valores relacionados ao fortalecimento da identidade cultural, posto que seu consumo vincula sua história em antigas tradições indígenas de consumo de beberagens. Uma vez considerando que não há um tempo próprio ou um lugar especial para aprendizagem de saberes, é possível concluir que inúmeros espaços e vivências cotidianas configuram-se como espaços de saber, portanto, como educativos, na medida em que possibilitam a circulação de sentidos e significados de teor pedagógico. Tal é o caso do preparo da manicuera que ocorre em espaços como o quintal das casas ou mesmo na rua, tornando-os lugares significativos para a transmissão e aprendizagens de saberes.

\section{Referências}

ALBUQUERQUE, M. B. B. Beberagens indígenas e educação não escolar no Brasil Colonial. Belém: FCPTN, 2012.

ARIÈS, P. História da morte no ocidente. Rio de Janeiro: EDIOURO, 2003. BRANDÃO, C. R. A educação como cultura. Campinas: Mercado de Letras, 2002.

CARDOSO, B. Salinópolis a cidade mais querida do Pará. Salinópolis: [s.n.], 2001. 
DANIEL, J. Tesouro descoberto no máximo rio Amazonas. v.1., Rio de Janeiro: Contraponto, 2004.

DAMATTA, R. A casa e a rua: espaço, cidadania, mulher e morte no Brasil. 5. Ed., Rio de Janeiro: Editora Rocco, 1997.

FERREIRA, D. Salinópolis da Memória. Belém: [s.n.], 2010.

GIARD, L. Artes de Nutrir. In: CERTEAU, M; GIARD, L; MAYIOL, P. A invenção do cotidiano: 2 morar, cozinhar. 9. Ed., Petrópolis: Vozes, 2009, pp. 211-233.

LEONEL, G. G. Festa e sociabilidade: reflexões teóricas e práticas para a pesquisa dos festejos como fenômenos urbanos contemporâneos. Cadernos de História, Belo Horizonte, v. 11, n. 15, p. 57. 2010.

NEGRÃO, M. V. N. Iluminando os mortos: um estudo sobre o ritual de homenagem aos mortos no Dia de Finados em Salinópolis-Pará. Belém (PA): UFPA, 2014 [Dissertação Mestrado em Antropologia].

PALHETA, A. Sal, Salinas, Salinópolis. Belém (PA): Imprensa Oficial do Estado, 2003.

REIS, J. J. A morte é uma festa: ritos fúnebres e revolta popular no Brasil do século XIX. São Paulo: Companhia das letras, 1991.

SANCHIS, P. Arraial: festa de um povo - as romarias portuguesas. Lisboa: Publicações Dom Quixote. 1983.

SOUZA, D. L. Turismo e urbanização turística no litoral paraense: o caso de Salinópolis-PA. Belém, 2011. Disponível em:<file:///C:/Users/Edson/AppData/ Local/Temp/artigo17.pdf>. Acesso em 15/11/2017.

SILVA, A. L.; MIGUEZ, P. Cultura, Festa e Cidade: tecendo relações. Revista Observatório da Diversidade Cultural, Belo Horizinte, v. 1, n. 1, p. 9. 2014. Disponível em: < <ttp://observatoriodadiversidade.org.br/revista/revista-odcvolume-n-01/>. Acesso em 15/11/2017.

THEVET, A. As singularidades da França Antártica. Tradução de Eugênio Amado. Belo Horizonte: Editora Itatiaia; São Paulo: EDUSP, 1978.

Data de recebimento: $20 / 04 / 2018$

Data de aceite: 30/05/2018 